\title{
Response Surface Analysis on the Effect of Temperature and pH on Growth and Proteolytic Activity of Thermophilic Bacillus sp.
}

\author{
Krystyna Gorlach-Lira ${ }^{1 *}$, Maria Lourdes Vieira Pedroza ${ }^{1}$, Aleksandra Burdziej-Pokojska ${ }^{2}$, \\ Henryk Rozycki ${ }^{2}$ and Hanna Dahm ${ }^{2}$ \\ ${ }^{1}$ Departamento de Biologia Molecular; Centro de Ciências Exatas e da Natureza; Universidade Federal da \\ Paraíba; Cidade Universitária - Campus I; 58059-900; João Pessoa - PB - Brasil. ${ }^{2}$ Department of Microbiology; \\ Institute of General and Molecular Biology; Nicholas Copernicus University; Torun - Poland
}

\begin{abstract}
Proteolytic activity and cell biomass of thermophilic Bacillus sp. strain were evaluated at various levels of initial pH and temperature by applying response surface methodology. The mineral medium containing yeast extract (0.01\%) and starch (1\%) was used throughout the experiment. The results of statistical analysis revealed the polynomial model with high coefficient of determination $\left(R^{2}=0.8\right)$ for the biomass and total proteolytic activity of the strain studied. This model showed a satisfactory adjustment of the statistic model with the experimental data. The $p$ values showed that the temperature and $\mathrm{pH}$ had significant effect on biomass and proteolytic activity $(P<0.05)$ of strain tested. The highest proteolytic activity $(2.333 \mathrm{U} / \mathrm{ml} / \mathrm{h})$ of the Bacillus sp. was predicted at $41^{\circ} \mathrm{C}$ and $\mathrm{pH}$ 4.8. The high biomass values were observed at broad range of temperature and $\mathrm{pH}$.
\end{abstract}

Key words: Bacillus, proteolytic activity, response surface methodology

\section{INTRODUCTION}

Thermophilic bacteria of genus Bacillus sp. receive great interest due to their biotechnological potential in relation to the production of variety of extracellular enzymes that are used in industrial scale. The proteases are one of the most important industrial enzymes in the world, used in laundry detergents, in leather preparation and food industry (Rao et al., 1998). It is well known that the effect of environmental conditions, such as nutrients, medium composition, variations of $\mathrm{pH}$ and temperature have strong effect on the production of proteases (Anwar and Saleemuddin, 1998;
Johnvesly and Naik, 2001; Nehete et al., 1985). Such parameters may be optimized by using the mathematical and statistical models that minimize the number of experiments, instead of the classical methods that involve changing one independent variable while unchanging all others at fixed level. The response surface methodology (RSM) that consists of factorial design and regression analysis, helps in evaluating the effective factors and building the models to study the interaction and select optimum conditions of variables for a desirable response (Beg et al., 2003; Myers and Montgomery, 2002). RSM was used to optimize the production of several extracellular enzymes

* Author for correspondence: kglira@yahoo.com 
such as xilanases (Bocchini et al., 2002), $\alpha$ amylase (Júnior et al., 2007; Tanyildizi et al, 2005), proteases (Beg et al., 2003; Puri et al., 2002; Thys et al., 2006) and $\beta$-glucanase (Tang et al., 2004; Tari et al., 2006) produced by several species of Bacillus sp. and other bacteria.

The aim of this study was to optimize the temperature and $\mathrm{pH}$ for the extracellular proteolytic enzymes produced by Bacillus sp. with the help of full-factorial composite design using RSM.

\section{MATERIAL AND METHODS}

\section{Bacterial strain and medium}

The thermophilic strain of Bacillus sp. TR17 isolated from the semi arid pasture soil of Northeast of Brasil was used in this study. The minimum and maximum growth temperature of strain studied was 30 and $65^{\circ} \mathrm{C}$, respectively. For the strain identification, the following analyses were used: API $50 \mathrm{CH}$ test (Biomerieux), Automatized Identification System Biolog (MicroLog System, Release 4.2, 2001) and Probabilistic Identification of Bacteria (PIB) (Bryant, 1995). The strain showed low similarity with Geobacillus thermoglucosidasius (R - 0.45) in the Biolog analysis, and high similarity (R 0.98 ) with Taxon 41 in the PIB analysis. The API $50 \mathrm{CH}$ pattern did not match with any standard strain of this test.

\section{Protease assay and biomass determination}

The minimal mineral medium $\left(0.05 \% \mathrm{CaCl}_{2} 2 \mathrm{H}_{2} \mathrm{O}\right.$, $\begin{array}{lllll}0.02 \% & \mathrm{KH}_{2} \mathrm{PO}_{4}, \quad 0.05 \% & \mathrm{MgSO}_{4} .7 \mathrm{H}_{2} \mathrm{O}, \quad 0.01 \%\end{array}$ $\mathrm{NaCl}$ ) with addition of $0.01 \%$ of yeast extract and one of the following substrate: glucose, glycerol and starch $\left(10 \mathrm{~g} \mathrm{l}^{-1}\right)$ was used to determine the best carbon source for the proteases production. The strain was incubated in $30 \mathrm{ml}$ of the medium at 40 ${ }^{\circ} \mathrm{C}$ and $\mathrm{pH} 7.0$ for $48 \mathrm{~h}$, after that the cultures were centrifuged at $6000 \mathrm{rpm}$ for $10 \mathrm{~min}\left(4^{\circ} \mathrm{C}\right)$, and then cell free supernatant was used for the estimation of proteolytic activity using azocasein (Sigma) as a substrate. The reaction mixture containing $0.5 \mathrm{ml}$ of cell-free supernatant, $0.5 \mathrm{ml}$ of $0.025 \%$ azocasein in $0.2 \mathrm{M}$ phosphate buffer ( $\mathrm{pH} 7.0$ ), was incubated for $30 \mathrm{~min}$ at $40^{\circ} \mathrm{C}$. The reaction mixture with water instead of supernatant was used as a control. After incubation, the reaction was stopped by addition of $1 \mathrm{ml}$ of $10 \%$ trichloroacetic acid, and after $30 \mathrm{~min}$, the solution was centrifuged at $12,000 \mathrm{rpm}$ for $15 \mathrm{~min}$. The optical density of the solution was measured at $420 \mathrm{~nm}$, and one unit of enzyme activity was defined as the quantity of enzyme that increased the absorbance of 1.0 in relation to blank. Total activity was expressed as unit $/ \mathrm{ml} / \mathrm{h}$. Total protein content in the cell-free supernatant was determined by Lowry et al. (1951) with bovine serine albumin as a protein standard. The biomass of Bacillus sp. was determined by drying the cells for $24 \mathrm{~h}$ at $100^{\circ} \mathrm{C}$.

\section{Experimental design}

After selection of best medium, the next stage was the determination of the optimal levels of two variables, initial $\mathrm{pH}(5.0-11.0)$ and temperature $\left(30-70^{\circ} \mathrm{C}\right)$, on protease production and bacterial growth. For this purpose, the response surface approach by using a set of experimental design (central composite design with five coded levels: $\sqrt{ } 2,-1,0,1, \sqrt{ } 2$ ) was performed. For two factors, the design was made up of a full $2^{3}$ factorial design with its eight points augmented with three replications of the centre points (both factors at level 0 ). The range and levels of experimental variables tested are presented in Table 1. The central values (zero level) chosen for the experimental design were $\mathrm{pH} 8.0$ and temperature $50{ }^{\circ} \mathrm{C}$. The set of 11 experiments that consisted of eight unique combinations and three replications in central point were carried out (Table 3).

The culture was grown in mineral medium that contained $0.01 \%$ yeast extract and $1 \%$ of starch, at $\mathrm{pH}$ and temperature designed for each experimental set for $48 \mathrm{~h}$. The biomass (mg of cells $/ \mathrm{ml})$, total activity $(\mathrm{U} / \mathrm{ml} /$ hour $)$ and protein content $(\mathrm{mg} / \mathrm{ml})$ were determined as described above. Results were analyzed by the Experimental Design Module of the Statistica software 6.0. The effect of each factor was evaluated by ANOVA (95\% and $99 \%)$. 
Table 1 - Experimental range and levels of the independent variables used.

\begin{tabular}{lcccccc}
\hline Variables & $\begin{array}{c}\text { Symbol } \\
\text { coded }\end{array}$ & \multicolumn{5}{c}{ Range and levels } \\
\hline & & $-\alpha(-\sqrt{ } 2)$ & -1 & 0 & 1 & $+\alpha(\sqrt{ } 2)$ \\
Temperature & $\mathrm{X}_{1}$ & 30.0 & 35.9 & 50.0 & 64.1 & 70.0 \\
$\mathrm{pH}$ & $\mathrm{X}_{2}$ & 5.0 & 5.9 & 8.0 & 10.1 & 11.0 \\
\hline
\end{tabular}

The model permitted the evaluation of the effects of linear, quadratic and interactive terms of the independent variables on the dependent variable. The response surface contour plots were drawn to illustrate the main and interactive effects of the independent variables on protease production. The optimum values of the selected variables were obtained by solving the regression equation and by analyzing the response surface contour plot.

\section{RESULTS AND DISCUSSION}

The biomass of Bacillus sp. varied from 9.0 to $15.0 \mathrm{mg} / \mathrm{ml}$ on different media, and its proteolytic activity was the highest in the mineral medium containing yeast extract and starch $\left(40^{\circ} \mathrm{C}, \mathrm{pH} 7.0\right)$ (Table 2). This medium was selected for further study on the proteolytic activity and biomass of Bacillus sp. that were analyzed as shown in Table 3.

Table 2 - Effect of substrate on total proteolytic activity and biomass of Bacillus sp. strain.

\begin{tabular}{lcccc}
\hline Strain & Yeast extract & $\begin{array}{c}\text { Yeast extract }+ \\
\text { Glucose }\end{array}$ & $\begin{array}{c}\text { Yeast extract }+ \\
\text { Starch }\end{array}$ & Yeast extract + Glycerol \\
\hline Total activity $(\mathrm{U} / \mathrm{ml})$ & $0.764 \pm 0.003^{*}$ & $1.031 \pm 0.006$ & $1.909 \pm 0.011$ & $0.819 \pm 0.005$ \\
& $15.00 \pm 0.120$ & $9.00 \pm 0.098$ & $12.00 \pm 0.100$ & $15.00 \pm 0.092$ \\
\hline Biomass $(\mathrm{mg} / \mathrm{ml})$ & & &
\end{tabular}

* Standard deviation

Table 3 - Experimental design used in response surface methodology studies showing observed extracellular proteins production, biomass and proteolytic activity of thermophilic Bacillus sp. strain.

\begin{tabular}{|c|c|c|c|c|c|c|c|}
\hline \multirow[t]{2}{*}{ Experiments } & \multicolumn{2}{|c|}{ Temperature $\left({ }^{\circ} \mathrm{C}\right)$} & \multicolumn{2}{|c|}{ pH } & \multirow{2}{*}{$\begin{array}{c}\text { Total } \\
\text { proteins } \\
\text { mg/ml }\end{array}$} & \multirow{2}{*}{$\begin{array}{l}\text { Biomass } \\
(\mathrm{mg} / \mathrm{ml})\end{array}$} & \multirow{2}{*}{$\begin{array}{l}\text { Total activity } \\
(\mathrm{U} / \mathrm{ml} / \mathrm{h})\end{array}$} \\
\hline & $\begin{array}{l}\text { Coded } \\
\text { values }\end{array}$ & True values & $\begin{array}{l}\text { Coded } \\
\text { values }\end{array}$ & $\begin{array}{c}\text { True } \\
\text { values }\end{array}$ & & & \\
\hline 1 & +1 & 64.1 & +1 & 10.1 & 0.310 & 23.00 & 0.936 \\
\hline 2 & -1 & 35.9 & +1 & 10.1 & 0.996 & 10.00 & 0.980 \\
\hline 3 & +1 & 64.1 & -1 & 5.9 & 0.331 & 18.00 & 0.920 \\
\hline 4 & -1 & 35.9 & -1 & 5.9 & 1.061 & 15.00 & 1.012 \\
\hline .5 & $+\sqrt{ } 2$ & 70.0 & 0 & 8.0 & 0.813 & 9.00 & 0.484 \\
\hline 6 & $-\sqrt{2}$ & 30.0 & 0 & 8.0 & 0.885 & 14.00 & 0.612 \\
\hline 7 & 0 & 50.0 & $+\sqrt{ } 2$ & 11.0 & 0.526 & 25.00 & 1.230 \\
\hline .8 & 0 & 50.0 & $-\sqrt{2}$ & 5.0 & 0.374 & 41.00 & 2.648 \\
\hline 9 & 0 & 50.0 & 0 & 8.0 & 0.584 & 35.00 & 1.620 \\
\hline 10 & 0 & 50.0 & 0 & 8.0 & 0.856 & 36.00 & 1.760 \\
\hline 11 & 0 & 50.0 & 0 & 8.0 & 0.694 & 38.00 & 1.840 \\
\hline
\end{tabular}

The growth of bacterial strain and protease production occurred in all the conditions tested (Table 3). According to the ANOVA results shown in Table 4, polynomial model obtained presented a high determination coefficient $\left(\mathrm{R}^{2}=0.85\right)$, showing good adjustment of the model to the experimental data. As indicated by $\mathrm{P}$ values, temperature showed significant quadratic effect and $\mathrm{pH}$ had linear effect on the proteolytic activity $(p<0,05)$. Temperature showed significant quadratic effect, and $\mathrm{pH}$ also linear effect, on the biomass $(\mathrm{p}<0,05)$ (Table 4$)$.

On the basis of experimental data showed in Table 3 , the following equations of the polynomial model for predicting the optimal point for total activity (TA) and biomass (B) were calculated: 
$\mathrm{TA}=5.185-0.001 \mathrm{x}^{2}{ }_{1}-0.777 \mathrm{x}_{2}+0.013 \mathrm{x}_{1} \cdot \mathrm{x}_{2}$

$\mathrm{B}=94.799-0.025 \mathrm{x}_{1}^{2}-15.478 \mathrm{x}_{2}-0.093 \mathrm{x}_{2}^{2}+$ $0.312 \mathrm{x}_{1} \cdot \mathrm{x}_{2}$

where $\mathrm{x}_{1}$ is temperature, and $\mathrm{x}_{2}$ is $\mathrm{pH}$.

Figs. 1 and 2 show the plots of response surface for the total proteolytic activity $(\mathrm{U} / \mathrm{ml} / \mathrm{h})$ and biomass (mg/ml) of Bacillus sp., respectively.
The region of high proteolytic activity (TA) of Bacillus sp. was identified with temperature values lower than $53^{\circ} \mathrm{C}$ and $\mathrm{pH}$ lower than 6.0 (TA > $2.042 \mathrm{U} / \mathrm{ml} / \mathrm{h}$ ) (Fig. 1). The model predicted a maximum response for proteolytic activity of $2.333 \mathrm{U} / \mathrm{ml} / \mathrm{h}$ at the point which was $\mathrm{pH} 4.8$ and temperature $41^{\circ} \mathrm{C}$.

Table 4 - Determination coefficient of polynomial model, $\mathrm{p}$ value and the interaction of temperature and $\mathrm{pH}$ for the variables tested. Values marked with asterisk are significant $(\mathrm{p}<0.05)$.

\begin{tabular}{lcc}
\hline Variable/Effect & $\begin{array}{c}\text { Biomass } \\
(\mathbf{m g} / \mathbf{m l})\end{array}$ & $\begin{array}{c}\text { Total activity } \\
(\mathbf{U} / \mathbf{m l} / \mathbf{h})\end{array}$ \\
\hline $\mathrm{R}^{2^{*}}$ & 0.846 & 0.831 \\
Value p - Linear & & \\
Temperature & 0.175 & 0.420 \\
pH & $0.034^{*}$ & $0.023^{*}$ \\
Value p - Quadratic & & \\
Temperature & $0.002^{*}$ & $0.004^{*}$ \\
pH & $0.040^{*}$ & 0.583 \\
Interaction & & \\
Temperature X pH & 0.082 & 0.849 \\
\hline
\end{tabular}

$\mathrm{R}^{2 *}$ - Determination coefficient

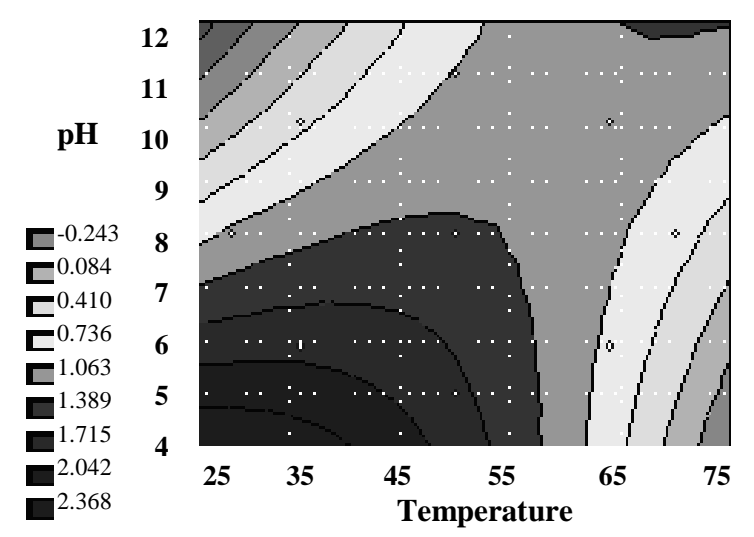

Figure 1 - Response surface curves for total proteolytic activity (U/ml/h) of Bacillus sp. as a function of temperature and $\mathrm{pH}$. 


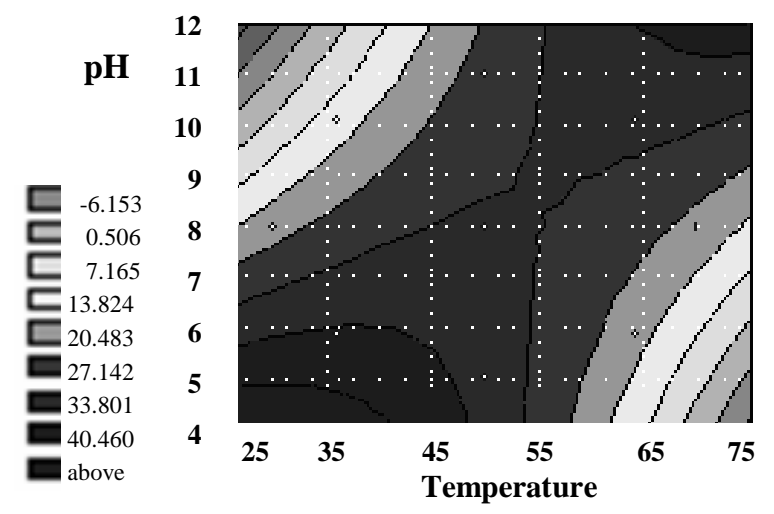

Figure 2 - Response surface curves for Bacillus sp. biomass (mg/ml) as a function of temperature and $\mathrm{pH}$.

The acid proteases produced by the thermophilic Bacillus spp. were characterized by Murao et al. (1988) and Toogood et al. (1995). Kim (2002) characterized the acid protease produced by $B$. subtilis JM-3, and reported that optimal $\mathrm{pH}$ and temperature were 5.5 and $60^{\circ} \mathrm{C}$, respectively. The high values of biomass on the level $33.8 \mathrm{mg} / \mathrm{ml}$ were observed in large range of temperature and $\mathrm{pH}$ (Fig. 2). For the temperature $<42^{\circ} \mathrm{C}$ the maximum biomass was achieved at $\mathrm{pH}<5.0$ (B) $40.46 \mathrm{mg} / \mathrm{ml}$ ).

Different applications of proteases require specific optimal $\mathrm{pH}$ for better enzyme activity. For example, the use of enzymes in the detergent industry requires alkaline $\mathrm{pH}$, while the acid proteases are widely used in cheese-making, baking and meat tenderization.

Various studies have reported the optimization of alkaline proteases production by Bacillus spp. using RSM (Adinarayana and Ellaiah, 2002; Beg et al., 2003; Ellaiah and Adinarayana, 2001; Puri et al., 2002). Wu and Hang (2000) studied the acid proteases using the response surface methodology.

\section{ACKNOWLEDGMENTS}

The authors thank Dr. Edy Sousa de Brito from Embrapa Agroindústria Tropical, Fortaleza-Ce, Brazil, for valuable suggestions and help in RSM analysis.

\section{RESUMO}

Atividade proteolítica total e biomassa de uma linhagem de Bacillus sp. termofílico foram analisados em vários níveis de $\mathrm{pH}$ inicial e temperatura utilizando a metodologia de superfície de resposta. $\mathrm{O}$ meio mineral com extrato de levedura $(0.01 \%)$ e amido ( $1 \%)$ foi utilizado no experimento. Os resultados de análise estatística da metodologia de resposta de superfície definiram um modelo polinomial para a biomassa e atividade proteolítica da linhagem de Bacillus sp. com alto coeficiente de determinação $\left(\mathrm{R}^{2}=0.8\right)$, mostrando um ajuste satisfatório do modelo estatístico obtido com os dados experimentais. Os valores de $p$ mostraram que a temperatura e $\mathrm{pH}$ tiveram efeito significante em biomassa e atividade total ( $P$ $<0.05)$ da linhagem testada. A atividade proteolítica mais alta $(2.368 \mathrm{U} / \mathrm{ml} / \mathrm{h})$ da linhagem de Bacilus sp. foi prevista pelas curvas de superfície de resposta em temperatura a $41^{\circ} \mathrm{C} \mathrm{e} \mathrm{pH}$ igual a 4.8. Os valores de biomassa altos foram previstos para ampla faixa de temperatura e $\mathrm{pH}$.

\section{REFERENCES}

Adinarayana, K.; Ellaiah, P. (2002), Response surface optimization of the critical medium components for the production of alkaline protease by a newly isolated Bacillus sp. J. Pharm. Sci., 5, 281-287.

Anwar, A.; Saleemuddin, T. (1998), Alkaline proteases: a review. Bioresource Technology, 64, 175-183. 
Beg, Q.K.; Sahai, V.; Gupta, R. (2003), Statistical media optimization and alkaline protease production from Bacillus mojavensis in a bioreactor. Process Biochem.,. 39, 203-209.

Bocchini, D. A.; Alves-Prado, H.F.; Baida, L.C.; Roberto, I. C.; Gomes, E.; Silva, R. (2002), Optimization of xylanase production by Bacillus circulans D1 in submerged fermentation using response surface methodology. Process Biochem., 38, 727-731.

Bryant, T.N. (1995), Probabilistic identification of bacteria (MS DOS software, release1.20). http://www.soton.ac.uk/staff/tnb/microsoftware/pib1 20.exe, 2005.

Ellaiah, P.; Adinarayana, K. (2001), Response surface optimization of the cultural conditions for the production of alcaline protease. J. Sci. Ind. Res., 60, 608-616.

Johnvesly, B.; Naik, G.R. (2001). Studies on production of thermostable alkaline protease from termophilic and alcaliphilic Bacillus sp. JB-99 in a chemically defined medium. Process Biochem., 37, 139-144.

Kim, S.M. (2002), Purification and characteristics of Bacillus subtilis JM-3 salt- and acid-tolerant protease derived from anchovy sauce. Annual Meeting and Food Expo, Anaheim, California.

Júnior J.B.S., Oliveira, L.S.S., Sardeiro, F.S., Souza, R.R., Lopes, F.L.G., Santana, J.C.C., Tambourgi, E.B. (2007), Response surface methodology to evaluation the recovery of amylases by hollow fiber membrane. Braz. Arch. Biol. Technol., 50, 713-718.

Lowry, O.H., Rosebrough, N.J., Farr, A.L., Randall, R.J. (1951), Protein measurement with the Folin phenol reagent. J. Biol. Chem., 193, 206-210.

Murao, S.; Okhuni, K.; Naganao, M. (1988), A novel thermostable S-PI (pepstatin Ac) - insensitive acid proteinase from thermophilic Bacillus sp. strain Mn32. Agr. Biol. Chem., 52, 1029-1031.

Myers, R.H.; Montgomery, D.C. (2002), Response surface methodology: process and product optimization using designed experiments. New York, Wiley.
Nehete, P.N.; Shah, V.D.; Kothari, R.M. (1985), Profiles of alkaline protease production as a function of composition of the slant, age, transfer and isolate number and physiological state of culture. Biotechnol. Lett., 7, 413-418.

Puri, S.; Beg, Q.H.; Gupta, R. (2002), Optimization of alkaline protease production from Bacillus sp. by response surface methodology. Current Microbiology, 44, 286-290.

Rao, M.B.; Tanksale, M.A.; Ghatge, M.S.; Deshpande, V.V. (1998), Molecular and biotechnological aspects of microbial proteases. Microbiol. Mol. Biol. Rev., 62, 597-635.

Tang, X-J.; He, G-Q.; Chen, Q-H.; Zhang, X-Y.; Ali, M.A.M. (2004), Medium optimization for the production of thermal stable $\beta$-glucanase by Bacillus subtilis ZJF-1A5 using response surface methodology. Bioresource Technology, 93, 175181.

Tanyildizi, M.S.; Ozer, D.; Elibol, M. (2005). Optimization of $\square$-amylase production by Bacillus sp. using response surface methodology. Process Biochem., 40, 2291-2296.

Tari, C.; Genckal, H.; Tokatli, F. (2006). Optimization of a growth medium using a statistical approach for the production of an alkaline protease from a newly isolated Bacillus sp. L21. Process Biochem., 41, 659-665.

Thys, R.C.S.; Guzzon, S.O.; Cladera-Olivera, F.; Brandelli, A. (2006). Optimization of protease production by Microbacterium sp. in feather meal using response surface methodology. Process Biochem., 41, 67-73.

Toogood, H.S.; Prescott, M.; Daniel, R.M. (1995). A pepstatin-insensitive aspartic proteinase from a thermoplilic Bacillus sp. J. Biochem., 307, 783-789.

Wu, L.C.; Hang, Y.D. (2000). Acid Protease Production from Neosartorya fischeri. LebensmittelWissenschaft und-Technologie, 33, 44-47.

Received: June 30, 2008; Revised: December 19, 2008; Accepted: October 21, 2009. 